\title{
Over-methylation of Histone H3 Lysines Is a Common Molecular Change Among the Three Major Types of Soft-tissue Sarcoma in Patient-derived Xenograft (PDX) Mouse Models
}

\author{
YUSUKE AOKI ${ }^{1,2,3}$, JUN YAMAMOTO $^{1,2,4}$, YASUNORI TOME ${ }^{3}$, KAZUYUKI HAMADA ${ }^{1,2}$, \\ NORIYUKI MASAKI ${ }^{1,2}$, SACHIKO INUBUSHI $^{5}$, YOSHIHIKO TASHIRO $^{1}$, \\ MICHAEL BOUVET $^{2}$, ITARU ENDO ${ }^{4}$, KOTARO NISHIDA $^{3}$ and ROBERT M. HOFFMAN ${ }^{1,2}$ \\ ${ }^{1}$ AntiCancer Inc, San Diego, CA, U.S.A.; \\ ${ }^{2}$ Department of Surgery, University of California San Diego, La Jolla, CA, U.S.A.; \\ ${ }^{3}$ Department of Orthopedic Surgery, Graduate School of Medicine, University of the Ryukyus, Nishihara, Japan; \\ ${ }^{4}$ Department of Gastroenterological Surgery, Yokohama City University Graduate School of Medicine, Yokohama, Japan; \\ ${ }^{5}$ Department of Breast and Endocrine Surgery, Kobe University Graduate School of Medicine, Hyogo, Japan
}

\begin{abstract}
Background/Aim: Sarcomas are considered a heterogeneous disease with incomplete understanding of its molecular basis. In the present study, to further understand general molecular changes in sarcoma, patient-derived xenograft (PDX) mouse models of the three most common soft-tissue sarcomas: myxofibrosarcoma, undifferentiated pleomorphic sarcoma (UPS) and liposarcoma were established and the methylation status of histone H3 lysine marks was studied. Materials and Methods: Immunoblotting and immunohistochemical staining were used to quantify the extent of methylation of histone H3K4me3 and histone H3K9me3. Results: In all 3 sarcoma types in PDX models, histone H3K4me 3 and H3K9me3 were found highly overmethylated compared to normal muscle tissue. Conclusion: Histone H3 lysine over-methylation may be a general basis of malignancy of the major sarcoma types.
\end{abstract}

Sarcomas are a heterogeneous group of cancers and the molecular basis of their malignancy is poorly understood (1$3)$. Histone methylation at lysine residues can control large numbers of genes, and is therefore a promising area to study

This article is freely accessible online.

Correspondence to: Robert M. Hoffman, AntiCancer Inc, 7917 Ostrow St, San Diego, CA, 92111, U.S.A.e-mail: all@anticancer.com and Yasunori Tome, Department of Orthopedic Surgery, Graduate School of Medicine, University of the Ryukyus, 207 Uehara, Nishihara, Okinawa, 903-0125, Japan. E-mail: yastome@med.uryukyu.ac.jp

Key Words: Sarcoma, PDX, histone H3, lysine, over-methylation, methionine-addiction. the basis of malignancy (4). Recently, there has been intense interest in the epigenetic control of cancer by specific histone methylation modifications, including histone $\mathrm{H} 3 \mathrm{~K} 4 \mathrm{me} 3$ and $\mathrm{H} 3 \mathrm{~K} 9 \mathrm{me} 3$, which are thought to be global gene regulators (5-7). H3K4me3 binds to gene-activating proteins, including transcription factors. $\mathrm{H} 3 \mathrm{~K} 9 \mathrm{me} 3$ is involved with repressing gene expression (4). Histone lysine marks appear to be overmethylated in some cancers $(5,6)$.

There have been a number of publications, in recent years, attempting to correlate the extent of methylation of histone H3 lysine with patient outcomes in cancers of the liver, cervix and colon, with inconclusive results (8-10).

In the present report, we show that the most common types of soft tissue sarcoma (STS), myxofibrosarcoma, undifferentiated pleomorphic sarcoma (UPS) and liposarcoma, growing in PDX mouse models, all have over-methylated histone $\mathrm{H} 3 \mathrm{~K} 4 \mathrm{me} 3$ and $\mathrm{H} 3 \mathrm{~K} 9 \mathrm{me} 3$ lysine marks, in contrast to normal muscle in the host nude mouse. Histone H3 lysine overmethylation is discussed as a potential general alteration in apparently heterogeneous types of sarcoma.

\section{Materials and Methods}

Mice. Athymic female nu/nu nude mice (AntiCancer, Inc., San Diego, CA, USA), 4-6 week old, average weight approximately 20 $\mathrm{g}$, were used to establish PDX mouse models of three types of STS: myxofibrosarcoma, undifferentiated pleomorphic sarcoma (UPS), liposarcoma. Each sarcoma tissue was implanted in 5 mice. All mice were maintained under standard conditions of $12 \mathrm{~h}$ light/dark cycles and fed autoclaved water and a laboratory rodent diet. All studies were performed with a protocol approved by an AntiCancer, Inc. Institutional Animal Care and Use Committee (IACUC) following the principles and procedures provided in the National Institutes of Health (NIH) Guide for the Care and Use of Animals under Assurance Number A3873-1. In order to minimize any suffering of 
the animals, they were anesthetized by subcutaneous injection of anesthesia and analgesics, which consist of $20 \mathrm{mg} / \mathrm{kg}$ ketamine, 15.2 $\mathrm{mg} / \mathrm{kg}$ xylazine, and $0.48 \mathrm{mg} / \mathrm{kg}$ acepromazine maleate, for all surgical experiments. In order ensure the depth of the anesthesia, animal response during surgery was monitored. The animals were sacrificed by $\mathrm{CO}_{2}$ inhalation humanely when they met the following humane endpoint criteria: severe tumor burden (more than $20 \mathrm{~mm}$ in diameter), prostration, significant body weight loss, difficulty breathing, rotational motion and body temperature drop. Tumor volume and body weight were measured once a week with the formula as follows: tumor volume $\left(\mathrm{mm}^{3}\right)=$ length $(\mathrm{mm}) \times$ width $(\mathrm{mm}) \times$ width $(\mathrm{mm}) \times 1 / 2(11-14)$.

\section{Patient-derived xenografts (PDX)}

Myxofibrosarcoma. A resected tumor tissue specimen resected from a 64-year-old woman with right anterior-thigh myxofibrosarcoma was previously obtained from surgery at the UCLA Medical Center, with written informed consent by the patient and Institutional Review Board approval (IRB\#10-001857), and transported immediately to the laboratory at AntiCancer, Inc. The tumor specimen was cut into 5- $\mathrm{mm}^{3}$ fragments, with 4 fragments implanted subcutaneously per mouse as previously reported (11). The time interval between tumor implantation and subsequent tumor harvest was approximately 3 months.

Undifferentiated pleomorphic sarcoma (UPS). A resected tumor tissue specimen resected from 65-year-old man with a right-high UPS was previously obtained at surgery at the UCLA Medical Center, with written informed patient consent and Institutional Review Board approval (IRB\#10-001857), and brought to AntiCancer, Inc. The tumor specimen was cut into $5-\mathrm{mm}^{3}$ fragments, with 4 fragments implanted per mouse as previously described $(12,13)$. The time interval between tumor implantation and subsequent tumor harvest was approximately 2 months.

Liposarcoma. A tumor specimen was resected from a 67-year-old man with upper-abdominal soft-tissue liposarcoma, at the UCLA Medical Center. The tumor was previously brought to AntiCancer, Inc., with written informed patient consent and Institutional Review Board approval (IRB\#10-001857). The tumor specimen was cut into 5- $\mathrm{mm}^{3}$ fragments, with 4 fragments implanted subcutaneously per mouse as described above (14). The time interval between tumor implantation and subsequent tumor harvest was approximately 4 months.

Immunoblotting. The sarcoma PDX mouse models were sacrificed and tumor and femoral muscle tissues were resected. Then tissues were frozen immediately after resection in liquid nitrogen. To prepare for immunoblotting, the tumors were homogenized and the histones were extracted using a Epiquik Total Histone Extraction Kit (Epigentek, Farmingdale, NY, USA). Immunoblotting for histones was performed with the following procedure: $12 \%$ SDS-PAGE gel-electrophoresis and transfer to $0.2 \mu \mathrm{m}$ polyvinylidene difluoride (PVDF) membranes were used. Blocking was performed using the Bullet Blocking One for Western Blotting Kit (Nakalai Tesque, Inc. Kyoto, Japan). AntiH3K4me3 antibody (1:1,000, \#9751, Cell Signaling Technology, Danvers, MA, USA); anti-H3K9me3 antibody (1:1,000, \#13969, Cell Signaling Technology); and anti-H3 antibody (1:1,500, 17168-1-AP, Proteintech, Rosemont, IL, USA) were used. Total histone H3 was used as a loading control. Horseradish-peroxidase-conjugated antirabbit IgG (1:20,000, SA00001-2, Proteintech) was used as a second antibody. Immunoreactivity was visualized using Clarity Western ECL
Substrate (Bio-Rad Laboratories, Hercules, CA, USA). The signals were detected with a UVP ChemStudio (Analytik Jena, Upland, CA, USA) $(6,7)$. Three repeated immunoblots were made for each sarcoma PDX. One homogenate was made per tumor and then analyzed on three separate gels.

Hematoxylin and eosin $(H \& E)$ staining. After resection of the sarcoma and femoral muscle tissues from PDX mice, the tissues were fixed with $10 \%$ formalin overnight before embedding in paraffin. The tumor and muscle tissues were sectioned and specimens were deparaffinized with xylene and rehydrated in a series of ethanol. Staining with H\&E was performed in accordance with standard protocol.

Immunohistochemical (IHC) staining. Tissues were prepared and sectioned as described above. Autoclaving was then performed in order to retrieve antigen at $120^{\circ} \mathrm{C}$ for $5 \mathrm{~min}$ with a citrate-buffer solution ( $\mathrm{pH}$ 6.0). Next, the specimens were immersed in absolute methanol containing $0.3 \%$ hydrogen peroxide solution in order to block endogenous peroxidase activity at room temperature for 30 minutes. Then, the specimens were blocked using $10 \%$ bovine serum albumin at room temperature for $15 \mathrm{~min}$ and incubated with $\mathrm{H} 3 \mathrm{~K} 4 \mathrm{me} 3$ antibody $(1: 1,000)$ at $4^{\circ} \mathrm{C}$ overnight. IHC reactions were detected with HistoFine (Nichirei, Tokyo, Japan) and Dako Omnis (Agilent, Santa Clara, CA, USA). Finally, the specimens were counterstained with hematoxylin $(6,7)$.

\section{Results}

Histone H3K4me3 and H3K9me3 in the sarcoma PDX are over-methylated compared to normal muscle. We evaluated the methylation status of histone marks H3K4me3 and H3K9me3 from the myxofibrosarcoma, UPS and liposarcoma grown in their corresponding PDX models. The tumor size at the end of the experiment was approximately $1,700 \mathrm{~mm}^{3}$. Histone H3K4me3 and H3K9me3 were over-methylated in all three sarcomas, compared to muscle tissue from the host mice, as seen by immunoblotting (Figure 1). Overmethylation of $\mathrm{H} 3 \mathrm{~K} 4 \mathrm{me} 3$ in all three sarcoma models was also demonstrated by immunohistochemistry (Figure 2).

Histology of each sarcoma type in the PDX model. H\&E staining showed that all three types of sarcomas have each maintained the histological characteristics of their original sarcoma type after growth in PDX mouse models (Figure 2). The myxofibrosarcoma PDX tissue comprised high-density spindle-shaped cancer cells with myxoid stroma. The UPS PDX tissue comprised high-density pleomorphic cells. The liposarcoma PDX tissue comprised both well differentiated and dedifferentiated cells.

\section{Discussion}

The present study showed that histone marks H3K4me3 and H3K9me3 were over-methylated in myxofibrosarcoma, UPS and liposarcoma, growing as PDX nude mice, in contrast to normal muscle from the host mice, which was only slightly 


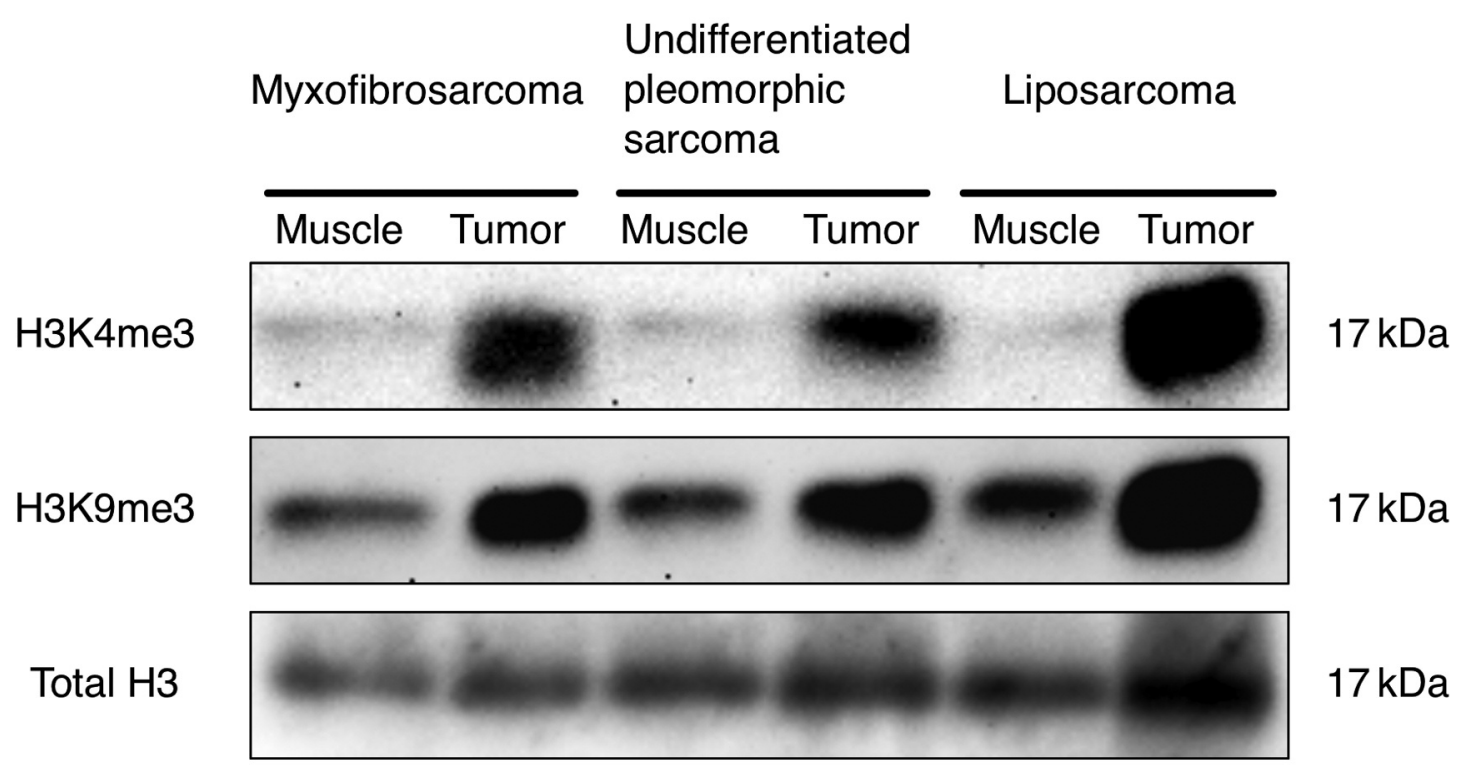

Figure 1. Immunoblotting of histone marks H3K4me3 and H3K9me3 from myxofibrosarcoma, undifferentiated pleomorphic sarcoma and liposarcoma and normal mouse muscle in patient-derived xenograft (PDX) models. Please see Materials and Methods for details.

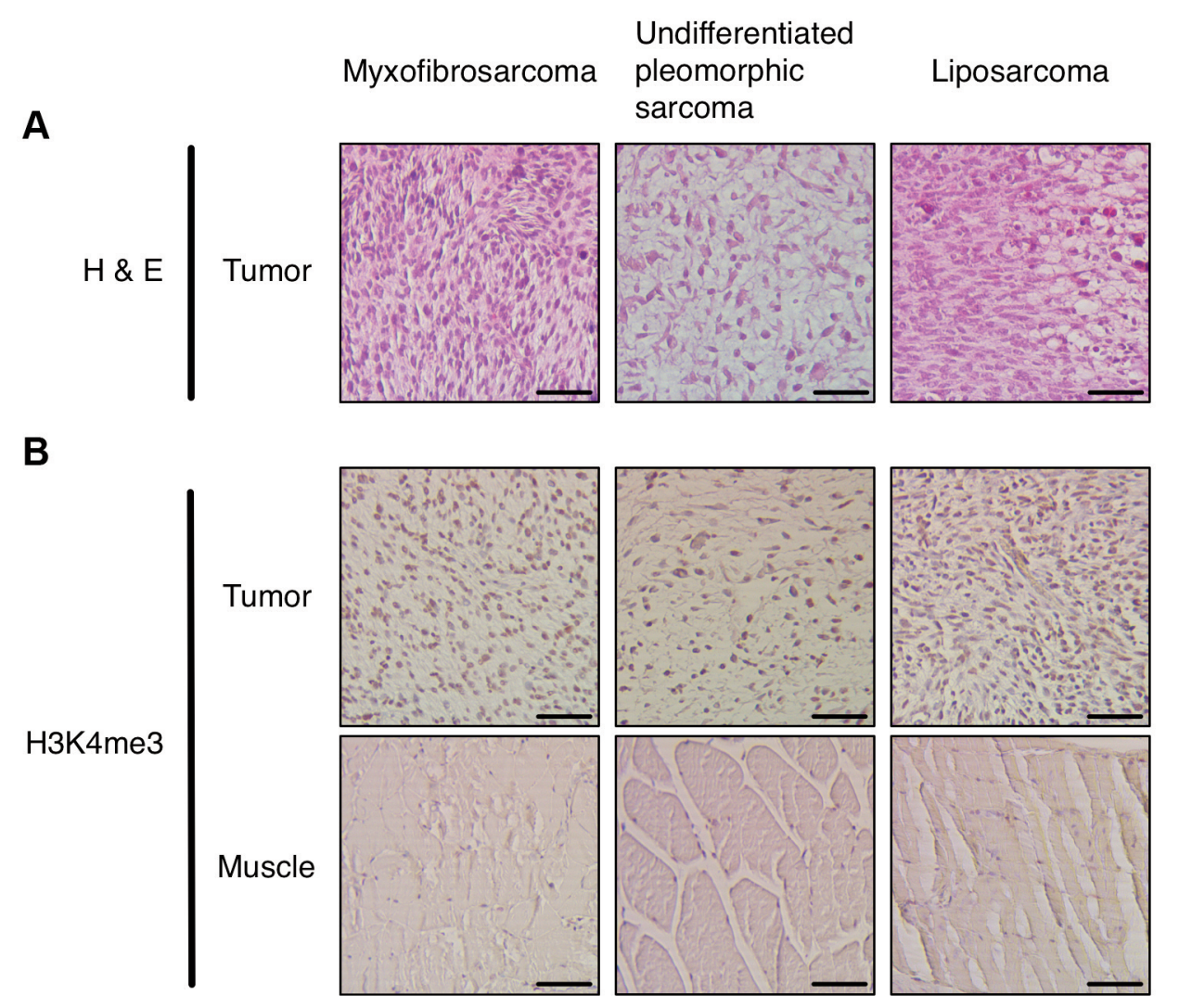

Figure 2. (A) Representative hematoxylin and eosin $(H \& E)$ staining images of myxofibrosarcoma, undifferentiated pleomorphic sarcoma and liposarcoma grown in patient-derived xenograft (PDX) mouse models. (B) Immunohistochemical staining for the histone mark H3K4me3 in myxofibrosarcoma, undifferentiated pleomorphic sarcoma and liposarcoma grown in PDX mouse models, and normal mouse muscle. Magnification: 100x. Scale bar: $50 \mu \mathrm{m}$. Please see Materials and Methods for details. 
methylated in histone H3K4me3 and H3K9me3 (Figure 1). This result is consistent with our previous report that histone $\mathrm{H} 3 \mathrm{~K} 4 \mathrm{me} 3$ and $\mathrm{H} 3 \mathrm{~K} 9 \mathrm{me} 3$ are over methylated in methionineaddicted cancer cell lines, but not in normal cells or in lowmalignancy methionine-independent revertants derived from the methionine-addicted cell lines $(6,7)$. This is the first report, to our knowledge, showing that histone H3K4me3 and/or $\mathrm{H} 3 \mathrm{~K} 9 \mathrm{me} 3$ are over-methylated in the 3 major types of sarcomas, suggesting a potential common mechanism of malignancy in apparently heterogeneous types of sarcoma.

Methionine addiction has been found in all properly-tested cancer cell types in vitro $(15,16)$ and in vivo (17). The present results of over-methylated histone $\mathrm{H} 3$ marks in the three sarcoma PDX types indicate they also may be methionine addicted. The present report and our previous reports $(6,7)$ suggest that over-methylation of histone $\mathrm{H} 3 \mathrm{~K} 4 \mathrm{me} 4$ and $\mathrm{H} 3 \mathrm{~K} 9 \mathrm{me} 3$ may be a general biomarker in cancer, since histone $\mathrm{H} 3$ lysine over-methylation is linked to methionine addiction, which is found in all major cancer types $(15,16)$.

In recent years, there have been a few published reports on histone $\mathrm{H} 3$ lysine marks methylation in soft tissue sarcoma. In one case, an isocitrate dehydrogenase (IHD) gene mutation altered gene expression of SOX9, COL2A1, CDKN1C, and ALPL, which was associated with an increase in both histone $\mathrm{H} 3 \mathrm{~K} 4 \mathrm{me} 3$ and $\mathrm{H} 3 \mathrm{~K} 9 \mathrm{me} 3$ methylation in chondrosarcoma cell lines and mesenchymal stem cells (18, 19). A de-differentiated liposarcoma was found to have higher levels of methylation of histone H3K9me3 compared to well-differentiated liposarcoma (20).

Histone $\mathrm{H} 3 \mathrm{~K} 4 \mathrm{me} 3$ and $\mathrm{H} 3 \mathrm{~K} 9 \mathrm{me} 3$ are thought to be global gene regulators and their over-methylation status may alter their function and change the expression of a large number of genes that result in malignant conversion of the cell. The overmethylation of $\mathrm{H} 3 \mathrm{~K} 4 \mathrm{me} 3$, which is involved in gene activation, and $\mathrm{H} 3 \mathrm{~K} 9 \mathrm{me} 3$, which is involved in gene repression, is a further indication of unbalanced transmethylation in cancer, a classical concept (21). Such unbalanced methylation of histones may have profound effects and importantly contribute to the malignant phenotype (6).

Future studies will correlate the malignant behavior, including survival or metastasis of the sarcomas, with overmethylation of histone $\mathrm{H} 3$ lysine marks, in patient-derived orthotopic xenograft (PDOX) models (22). Future studies will also use other methods to investigate epigenetic modifications of histones in cancer, such as ChIP (23). The overmethylation of $\mathrm{H} 3 \mathrm{~K} 4 \mathrm{me} 3$ and $\mathrm{H} 3 \mathrm{~K} 9 \mathrm{me} 3$ found in the 3 major types of sarcoma in the present study may be related to methionine addiction, a fundamental hallmark of cancer (2428), termed the Hoffman effect (29-31). The over-methylation of these histone marks required excess methionine in the form of S-adenosylmethionine and may, at least in part, account for the excess methionine required by cancer cells and is a basis why methionine restriction with recombinant methioninase has been an effective therapy for sarcoma in all major types of sarcoma PDOX models (32-46).

\section{Conflicts of Interest}

The Authors declare that there are no potential conflicts of interest.

\section{Authors' Contributions}

YA, JY, YT and RMH were involved in study conception and design. YA, JY, KH, NM and RMH were involved in acquisition of data. YA, JY, YT, KH, NM, SI, MB, IE, KN and RMH analyzed and interpreted data. YA, YT and RMH wrote this manuscript. All Authors reviewed and approved the manuscript.

\section{Acknowledgements}

The study was supported, in part, by the Robert M. Hoffman Foundation for Cancer Research, which had no role in the direction of the research. This paper is dedicated to the memory of A. R. Moossa, MD, Sun Lee, MD, Professor Li Jiaxi and Masaki Kitajima, MD.

\section{References}

1 Mariño-Enríquez A and Bovée JV: Molecular pathogenesis and diagnostic, prognostic and predictive molecular markers in sarcoma. Surg Pathol Clin 9(3): 457-473, 2016. PMID: 27523972. DOI: 10.1016/j.path.2016.04.009

2 Dancsok AR, Asleh-Aburaya K and Nielsen TO: Advances in sarcoma diagnostics and treatment. Oncotarget 8(4): 7068-7093, 2017. PMID: 27732970. DOI: 10.18632/oncotarget.12548

3 Bourcier K, Le Cesne A, Tselikas L, Adam J, Mir O, Honore C and de Baere T: Basic knowledge in soft tissue sarcoma. Cardiovasc Intervent Radiol 42(9): 1255-1261, 2019. PMID: 31236647. DOI: 10.1007/s00270-019-02259-w

4 Michalak EM, Burr ML, Bannister AJ and Dawson MA: The roles of DNA, RNA and histone methylation in ageing and cancer. Nat Rev Mol Cell Biol 20(10): 573-589, 2019. PMID: 31270442. DOI: 10.1038/s41580-019-0143-1

5 Wang Z, Yip LY, Lee JHJ, Wu Z, Chew HY, Chong PKW, Teo CC, Ang HY, Peh KLE, Yuan J, Ma S, Choo LSK, Basri N, Jiang X, Yu Q, Hillmer AM, Lim WT, Lim TKH, Takano A, Tan EH, Tan DSW, Ho YS, Lim B and Tam WL: Methionine is a metabolic dependency of tumor-initiating cells. Nat Med 25(5): 825-837, 2019. PMID: 31061538. DOI: 10.1038/s41591-019-0423-5

6 Yamamoto J, Han Q, Inubushi S, Sugisawa N, Hamada K, Nishino H, Miyake K, Kumamoto T, Matsuyama R, Bouvet M, Endo I and Hoffman RM: Histone methylation status of $\mathrm{H} 3 \mathrm{~K} 4 \mathrm{me} 3$ and $\mathrm{H} 3 \mathrm{~K} 9 \mathrm{me} 3$ under methionine restriction is unstable in methionine-addicted cancer cells, but stable in normal cells. Biochem Biophys Res Commun 533(4): 10341038, 2020. PMID: 33019978. DOI: 10.1016/j.bbrc.2020.09.108

7 Yamamoto J, Inubushi S, Han Q, Tashiro Y, Sugisawa N, Hamada K, Aoki Y, Miyake K, Matsuyama R, Bouvet M, Clarke $\mathrm{S}$, Endo I and Hoffman R: The linkage of methionine addiction, overmethylation of histone $\mathrm{H} 3$ lysines and malignancy 
demonstrated when cancer cells revert to methionineindependence. bioRxiv, 2021. DOI: 10.1101/2020.12.04.412437

$8 \mathrm{He}$ C, Xu J, Zhang J, Xie D, Ye H, Xiao Z, Cai M, Xu K, Zeng $\mathrm{Y}$, Li H and Wang J: High expression of trimethylated histone $\mathrm{H} 3$ lysine 4 is associated with poor prognosis in hepatocellular carcinoma. Hum Pathol 43(9): 1425-1435, 2012. PMID: 22406368. DOI: 10.1016/j.humpath.2011.11.003

9 Beyer S, Zhu J, Mayr D, Kuhn C, Schulze S, Hofmann S, Dannecker C, Jeschke U and Kost BP: Histone H3 acetyl K9 and histone $\mathrm{H} 3$ tri methyl $\mathrm{K} 4$ as prognostic markers for patients with cervical cancer. Int J Mol Sci 18(3): 477, 2017. PMID: 28241481. DOI: $10.3390 /$ ijms 18030477

10 Benard A, Goossens-Beumer IJ, van Hoesel AQ, de Graaf W, Horati H, Putter H, Zeestraten EC, van de Velde CJ and Kuppen PJ: Histone trimethylation at $\mathrm{H} 3 \mathrm{~K} 4, \mathrm{H} 3 \mathrm{~K} 9$ and $\mathrm{H} 4 \mathrm{~K} 20$ correlates with patient survival and tumor recurrence in earlystage colon cancer. BMC Cancer 14: 531, 2014. PMID: 25047223. DOI: 10.1186/1471-2407-14-531

11 Kiyuna T, Tome Y, Murakami T, Miyake K, Igarashi K, Kawaguchi K, Oshiro H, Higuchi T, Miyake M, Sugisawa N, Zhang Z, Razmjooei S, Wangsiricharoen S, Chmielowski B, Nelson SD, Russell TA, Dry SM, Li Y, Eckardt MA, Singh AS, Chawla S, Kanaya F, Eilber FC, Singh SR, Zhao M and Hoffman RM: A combination of irinotecan/cisplatinum and irinotecan/temozolomide or tumor-targeting Salmonella typhimurium A1-R arrest doxorubicin- and temozolomide-resistant myxofibrosarcoma in a PDOX mouse model. Biochem Biophys Res Commun 505(3): 733 739, 2018. PMID: 30292411. DOI: 10.1016/j.bbrc.2018.09.106

12 Kiyuna T, Murakami T, Tome Y, Igarashi K, Kawaguchi K, Russell T, Eckardt MA, Crompton J, Singh A, Bernthal N, Bukata S, Federman N, Kanaya F, Eilber FC and Hoffman RM: Labeling the stroma of a patient-derived orthotopic xenograft (PDOX) mouse model of undifferentiated pleomorphic softtissue sarcoma with red fluorescent protein for rapid noninvasive imaging for drug screening. J Cell Biochem 118(2): 361-365, 2017. PMID: 27357060. DOI: 10.1002/jcb.25643

13 Murakami T, DeLong J, Eilber FC, Zhao M, Zhang Y, Zhang N, Singh A, Russell T, Deng S, Reynoso J, Quan C, Hiroshima Y, Matsuyama R, Chishima T, Tanaka K, Bouvet M, Chawla S, Endo I and Hoffman RM: Tumor-targeting Salmonella typhimurium A1-R in combination with doxorubicin eradicate soft tissue sarcoma in a patient-derived orthotopic xenograft (PDOX) model. Oncotarget 7(11): 12783-12790, 2016. PMID: 26859573. DOI: 10.18632 oncotarget.7226

14 Kiyuna T, Murakami T, Tome Y, Igarashi K, Kawaguchi K, Miyake K, Miyake M, Li Y, Nelson SD, Dry SM, Singh AS, Russell TA, Singh SR, Kanaya F, Eilber FC and Hoffman RM: Doxorubicin-resistant pleomorphic liposarcoma with PDGFRA gene amplification is targeted and regressed by pazopanib in a patient-derived orthotopic xenograft mouse model. Tissue Cell 53: 30-36, 2018. PMID: 30060824. DOI: 10.1016/j.tice.2018.05.010

15 Mecham JO, Rowitch D, Wallace CD, Stern PH and Hoffman RM: The metabolic defect of methionine dependence occurs frequently in human tumor cell lines. Biochem Biophys Res Commun 117(2): 429-434, 1983. PMID: 6661235. DOI: 10.1016/0006-291x(83)91218-4

16 Tan Y, Xu M and Hoffman RM: Broad selective efficacy of recombinant methioninase and polyethylene glycol-modified recombinant methioninase on cancer cells In Vitro. Anticancer Res 30(4): 1041-1046, 2010. PMID: 20530407.
17 Breillout F, Antoine E and Poupon MF: Methionine dependency of malignant tumors: a possible approach for therapy. J Natl Cancer Inst 82(20): 1628-1632, 1990. PMID: 2213904. DOI: $10.1093 /$ jnci/82.20.1628

18 Jin Y, Elalaf H, Watanabe M, Tamaki S, Hineno S, Matsunaga K, Woltjen K, Kobayashi Y, Nagata S, Ikeya M, Kato T Jr, Okamoto T, Matsuda S and Toguchida J: Mutant IDH1 dysregulates the differentiation of mesenchymal stem cells in association with gene-specific histone modifications to cartilageand bone-related genes. PLoS One 10(7): e0131998, 2015. PMID: 26161668. DOI: 10.1371/journal.pone.0131998

19 Nakagawa M, Nakatani F, Matsunaga H, Seki T, Endo M, Ogawara Y, Machida Y, Katsumoto T, Yamagata K, Hattori A, Fujita S, Aikawa Y, Ishikawa T, Soga T, Kawai A, Chuman H, Yokoyama N, Fukushima S, Yahiro K, Kimura A, Shimada E, Hirose T, Fujiwara T, Setsu N, Matsumoto Y, Iwamoto Y, Nakashima Y and Kitabayashi I: Selective inhibition of mutant IDH1 by DS-1001b ameliorates aberrant histone modifications and impairs tumor activity in chondrosarcoma. Oncogene 38(42): 6835-6849, 2019. PMID: 31406254. DOI: 10.1038/s41388-019-0929-9

20 Keung EZ, Akdemir KC, Al Sannaa GA, Garnett J, Lev D, Torres KE, Lazar AJ, Rai K and Chin L: Increased H3K9me3 drives dedifferentiated phenotype via KLF6 repression in liposarcoma. J Clin Invest 125(8): 2965-2978, 2015. PMID: 26193637. DOI: $10.1172 /$ JCI77976

21 Borek E and Srinivasan P: The methylation of nucleic acids. Annual Review of Biochemistry 35(1): 275-298, 2017. DOI: 10.1146/annurev.bi.35.070166.001423

22 Igarashi K, Kawaguchi K, Murakami T, Miyake K, Kiyuna T, Miyake M, Hiroshima Y, Higuchi T, Oshiro H, Nelson SD, Dry SM, Li Y, Yamamoto N, Hayashi K, Kimura H, Miwa S, Singh SR, Tsuchiya H and Hoffman RM: Patient-derived orthotopic xenograft models of sarcoma. Cancer Lett 469: 332-339, 2020. PMID: 31639427. DOI: 10.1016/j.canlet.2019.10.028

23 Barski A, Cuddapah S, Cui K, Roh TY, Schones DE, Wang Z, Wei G, Chepelev I and Zhao K: High-resolution profiling of histone methylations in the human genome. Cell 129(4): 823837, 2007. PMID: 17512414. DOI: 10.1016/j.cell.2007.05.009

24 Hoffman RM and Erbe RW: High in vivo rates of methionine biosynthesis in transformed human and malignant rat cells auxotrophic for methionine. Proc Natl Acad Sci USA 73(5): 1523-1527, 1976. PMID: 179090. DOI: 10.1073/pnas. 73.5.1523

25 Coalson DW, Mecham JO, Stern PH and Hoffman RM: Reduced availability of endogenously synthesized methionine for Sadenosylmethionine formation in methionine-dependent cancer cells. Proc Natl Acad Sci USA 79(14): 4248-4251, 1982. PMID: 6289297. DOI: $10.1073 /$ pnas.79.14.4248

26 Stern PH, Wallace CD and Hoffman RM: Altered methionine metabolism occurs in all members of a set of diverse human tumor cell lines. J Cell Physiol 119(1): 29-34, 1984. PMID: 6707100. DOI: $10.1002 /$ jcp.1041190106

27 Stern PH and Hoffman RM: Elevated overall rates of transmethylation in cell lines from diverse human tumors. In Vitro 20(8): 663-670, 1984. PMID: 6500606. DOI: 10.1007/BF02619617

28 Hoffman RM and Jacobsen SJ: Reversible growth arrest in simian virus 40-transformed human fibroblasts. Proc Natl Acad Sci USA 77(12): 7306-7310, 1980. PMID: 6261250. DOI: 10.1073/pnas.77.12.7306 
29 Kaiser P: Methionine dependence of cancer. Biomolecules 10(4): 568, 2020. PMID: 32276408. DOI: 10.3390/biom10040568

30 Lauinger L and Kaiser P: Sensing and signaling of methionine metabolism. Metabolites 11(2): 83, 2021. PMID: 33572567. DOI: $10.3390 /$ metabo11020083

31 Borrego SL, Fahrmann J, Hou J, Lin DW, Tromberg BJ, Fiehn $\mathrm{O}$ and Kaiser P: Lipid remodeling in response to methionine stress in MDA-MBA-468 triple-negative breast cancer cells. J Lipid Res 62: 100056, 2021. PMID: 33647277. DOI: 10.1016/j.jlr.2021.100056

32 Murakami T, Li S, Han Q, Tan Y, Kiyuna T, Igarashi K, Kawaguchi K, Hwang HK, Miyake K, Singh AS, Nelson SD, Dry SM, Li Y, Hiroshima Y, Lwin TM, DeLong JC, Chishima T, Tanaka K, Bouvet M, Endo I, Eilber FC and Hoffman RM: Recombinant methioninase effectively targets a Ewing's sarcoma in a patient-derived orthotopic xenograft (PDOX) nude-mouse model. Oncotarget 8(22): 35630-35638, 2017. PMID: 28404944. DOI: $10.18632 /$ oncotarget.15823

33 Miyake K, Kiyuna T, Li S, Han Q, Tan Y, Zhao M, Oshiro H, Kawaguchi K, Higuchi T, Zhang Z, Razmjooei S, Barangi M, Wangsiricharoen S, Murakami T, Singh AS, Li Y, Nelson SD, Eilber FC, Bouvet M, Hiroshima Y, Chishima T, Matsuyama R, Singh SR, Endo I and Hoffman RM: Combining tumor-selective bacterial therapy with Salmonella typhimurium A1-R and cancer metabolism targeting with oral recombinant methioninase regressed an Ewing's sarcoma in a patient-derived orthotopic xenograft model. Chemotherapy 63(5): 278-283, 2018. PMID: 30673664. DOI: $10.1159 / 000495574$

34 Igarashi K, Li S, Han Q, Tan Y, Kawaguchi K, Murakami T, Kiyuna T, Miyake K, Li Y, Nelson SD, Dry SM, Singh AS, Elliott IA, Russell TA, Eckardt MA, Yamamoto N, Hayashi K, Kimura H, Miwa S, Tsuchiya H, Eilber FC and Hoffman RM: Growth of doxorubicin-resistant undifferentiated spindle-cell sarcoma PDOX is arrested by metabolic targeting with recombinant methioninase. J Cell Biochem 119(4): 3537-3544, 2018. PMID: 29143983. DOI: 10.1002/jcb.26527

35 Igarashi K, Kawaguchi K, Kiyuna T, Miyake K, Miyaki M, Yamamoto N, Hayashi K, Kimura H, Miwa S, Higuchi T, Singh AS, Chmielowski B, Nelson SD, Russell TA, Eckardt MA, Dry SM, Li Y, Singh SR, Chawla SP, Eilber FC, Tsuchiya H and Hoffman RM: Metabolic targeting with recombinant methioninase combined with palbociclib regresses a doxorubicin-resistant dedifferentiated liposarcoma. Biochem Biophys Res Commun 506(4): 912-917, 2018. PMID: 30392912. DOI: 10.1016/j.bbrc. 2018.10.119

36 Igarashi K, Kawaguchi K, Li S, Han Q, Tan Y, Gainor E, Kiyuna T, Miyake K, Miyake M, Higuchi T, Oshiro H, Singh AS, Eckardt MA, Nelson SD, Russell TA, Dry SM, Li Y, Yamamoto N, Hayashi K, Kimura H, Miwa S, Tsuchiya H, Eilber FC and Hoffman RM: Recombinant methioninase combined with doxorubicin (DOX) regresses a DOX-resistant synovial sarcoma in a patient-derived orthotopic xenograft (PDOX) mouse model. Oncotarget 9(27): 19263-19272, 2018. PMID: 29721200. DOI: 10.18632 /oncotarget. 24996

37 Igarashi K, Kawaguchi K, Li S, Han Q, Tan Y, Murakami T, Kiyuna T, Miyake K, Miyake M, Singh AS, Eckardt MA, Nelson SD, Russell TA, Dry SM, Li Y, Yamamoto N, Hayashi K, Kimura H, Miwa S, Tsuchiya H, Singh SR, Eilber FC and Hoffman RM: Recombinant methioninase in combination with doxorubicin (DOX) overcomes first-line DOX resistance in a patient-derived orthotopic xenograft nude-mouse model of undifferentiated spindle-cell sarcoma. Cancer Lett 417: 168-173, 2018. PMID: 29306021. DOI: 10.1016/j.canlet.2017.12.028

38 Igarashi K, Kawaguchi K, Kiyuna T, Miyake K, Miyake M, Li S, Han Q, Tan Y, Zhao M, Li Y, Nelson SD, Dry SM, Singh AS, Elliott IA, Russell TA, Eckardt MA, Yamamoto N, Hayashi K, Kimura H, Miwa S, Tsuchiya H, Eilber FC and Hoffman RM: Tumor-targeting Salmonella typhimurium A1-R combined with recombinant methioninase and cisplatinum eradicates an osteosarcoma cisplatinum-resistant lung metastasis in a patient-derived orthotopic xenograft (PDOX) mouse model: decoy, trap and kill chemotherapy moves toward the clinic. Cell Cycle 17(6): 801-809, 2018. PMID: 29374999. DOI: $10.1080 / 15384101.2018 .1431596$

39 Higuchi T, Kawaguchi K, Miyake K, Han Q, Tan Y, Oshiro H, Sugisawa N, Zhang Z, Razmjooei S, Yamamoto N, Hayashi K, Kimura H, Miwa S, Igarashi K, Chawla SP, Singh AS, Eilber FC, Singh SR, Tsuchiya H and Hoffman RM: Oral recombinant methioninase combined with caffeine and doxorubicin induced regression of a doxorubicin-resistant synovial sarcoma in a PDOX mouse model. Anticancer Res 38(10): 5639-5644, 2018. PMID: 30275182. DOI: 10.21873/anticanres.12899

40 Higuchi T, Oshiro H, Miyake K, Sugisawa N, Han Q, Tan Y, Park J, Zhang Z, Razmjooei S, Yamamoto N, Hayashi K, Kimura H, Miwa S, Igarashi K, Bouvet M, Chawla SP, Singh SR, Tsuchiya $\mathrm{H}$ and Hoffman RM: Oral recombinant methioninase, combined with oral caffeine and injected cisplatinum, overcome cisplatinum-resistance and regresses patient-derived orthotopic xenograft model of osteosarcoma. Anticancer Res 39(9): 4653-4657, 2019. PMID: 31519563. DOI: 10.21873/anticanres.13646

41 Hoffman RM, Murakami T, Kawaguchi K, Igarashi K, Tan Y, Li S and Han Q: High efficacy of recombinant methioninase on patient-derived orthotopic xenograft (PDOX) mouse models of cancer. Methods Mol Biol 1866: 149-161, 2019. PMID: 30725414. DOI: 10.1007/978-1-4939-8796-2_12

42 Igarashi K, Kawaguchi K, Zhao M, Han Q, Tan Y, Kiyuna T, Miyake K, Higuchi T, Nelson SD, Dry SM, Li Y, Yamamoto N, Hayashi K, Kimura H, Miwa S, Singh SR, Tsuchiya H and Hoffman RM: Recombinant methioninase combined with tumortargeting Salmonella typhimurium A1-R induced regression in a PDOX mouse model of doxorubicin-resistant dedifferentiated liposarcoma. Anticancer Res 40(5): 2515-2523, 2020. PMID: 32366396. DOI: 10.21873/anticanres.14222

43 Higuchi T, Han Q, Miyake K, Oshiro H, Sugisawa N, Tan Y, Yamamoto N, Hayashi K, Kimura H, Miwa S, Igarashi K, Bouvet M, Singh SR, Tsuchiya $\mathrm{H}$ and Hoffman RM: Combination of oral recombinant methioninase and decitabine arrests a chemotherapy-resistant undifferentiated soft-tissue sarcoma patient-derived orthotopic xenograft mouse model. Biochem Biophys Res Commun 523(1): 135-139, 2020. PMID: 31839218. DOI: 10.1016/j.bbrc.2019.12.024

44 Higuchi T, Sugisawa N, Yamamoto J, Oshiro H, Han Q, Yamamoto N, Hayashi K, Kimura H, Miwa S, Igarashi K, Tan Y, Kuchipudi S, Bouvet M, Singh SR, Tsuchiya H and Hoffman RM: The combination of oral-recombinant methioninase and azacitidine arrests a chemotherapy-resistant osteosarcoma patient-derived orthotopic xenograft mouse model. Cancer Chemother Pharmacol 85(2): 285-291, 2020. PMID: 31705268. DOI: $10.1007 / \mathrm{s} 00280-019-03986-0$ 
45 Higuchi T, Han Q, Sugisawa N, Yamamoto J, Yamamoto N, Hayashi K, Kimura H, Miwa S, Igarashi K, Bouvet M, Singh SR, Tsuchiya H and Hoffman RM: Combination methioninemethylation-axis blockade: A novel approach to target the methionine addiction of cancer. Cancer Genomics Proteomics 18(2): 113-120, 2021. PMID: 33608308. DOI: 10.21873/ cgp. 20246

46 Aoki Y, Tome Y, Wu NF, Yamamoto J, Hamada K, Han Q, Bouvet M, Nishida $\mathrm{K}$ and Hoffman RM: Oral-recombinant methioninase converts an osteosarcoma from docetaxel-resistant to -sensitive in a clinically-relevant patient-derived orthotopicxenograft (PDOX) mouse model. Anticancer Res 41(4): 17451751, 2021. PMID: 33813378. DOI: 10.21873/anticanres.14939

Received July 22, 2021

Revised August 21, 2021

Accepted September 7, 2021 